\title{
Technological Stripping and Meaning Production in Duchamp's The Large Glass
}

\author{
Monika Włudzik \\ Department of English Philology \\ Nicolaus Copernicus University in Toruń \\ monikawludzik[]gmail.com \\ Received September 2013; accepted December 2013; published Summer 2014.
}

\begin{abstract}
The scope of the essay is limited by the ideas behind the mechanisation of desire as conceptualised in The Large Glass by Marcel Duchamp. This glassbased installation depicts a convoluted mechanism, as the full-title of the work suggests, representing The Bride Stripped Bare by her Bachelors, Even. Using tropes and figures from his earlier studies, the artist designed a machine for the production of desire, rendering the unconscious mechanical and dynamic. The paper aims to present selected aspects of the installation, including mechanical reproduction (1), technological fetishism (2), transparency (3), as well as to discuss its significance with reference to Deleuze and Guattari's concept of the Body without Organs (4). The interpretive force of the machine metaphor in the work of Duchamp is analysed in the context of integrative and non-integrative attitudes to technology.
\end{abstract}

Keywords: Duchamp; technological fetishism; mechanical reproduction; Deleuze and Guattari; Body without Organs.

Glass panes, even large ones, although certainly interesting in their own right, may seem rather unremarkable. That is not, however, the case with Marcel Duchamp whose glass-based installation ${ }^{72}$ depicts a complex mechanism, as the full-title of the work suggests, representing The Bride Stripped Bare by her Bachelors, Even. By invoking a familiar artistic theme, reminescent of Renaissance renderings of the encounter between Susannah and the Elders, the artist fuses modern obsessions with technology and eroticism to design a ma-

\footnotetext{
${ }^{72}$ The present article concentrates on the mechanism itself, largely omitting separate elements of the machinery and their functions elaborated on in the artist's notes and separate studies. Similarly, the installation Given, often regarded as complementary to The Bride Stripped Bare by her Bachelors, Even is not discussed in this article.
} 
chine for the production of desire. In his characteristic tongue-in-cheek fashion, Duchamp undermines the aesthetic qualities of nudity, along with the notions of progress, utility and efficiency, supplementing his work with copious notes that explain the overall working process of the machine. The paper aims to present selected aspects of the installation, including mechanical reproduction (1), technological fetishism (2), transparency (3), as well as to discuss its significance with reference to Deleuze and Guattari's concept of the body without organs (4), hoping to provide a synthetical view of the work.

The Large Glass is executed on two about 3 metre tall glass planes with the use of wire, lead foil, paint and dust. When the installation was first exhibited in 1926, Marcel Duchamp had been working on it for about ten years, specifying different processes of the machine and studying its separate parts in his other works $^{73}$. In the same period, the artist worked on his readymades ${ }^{74}$, a name he gave to randomly chosen objects, which in a gesture of artistic elevation became deprived of their original purpose and acquired artistic value. This incorporation of mass-manufactured objects in Duchamp's work could be seen as pertaining to both mimicry and mockery of what is conventionally understood as art, or rather artistic production, for he rejected the idea of artistic skill and embraced aesthetic value as "an act of mental distancing" (Seigel 1997: 116). The shortened descriptive title of the installation suggests that it is nothing less than a large pane of glass, implying a connection with the readymades, such as the bottle rack, the bicycle wheel, or the urinal. Still, The Large Glass may also be said to reverse the theme of artistic non-production, since it is accompanied by boxes of notes by the artist ${ }^{75}$ that specify the purpose of the machine and its overall movements. The preparatory, rather than explanatory, notes document the creative process that found its culmination in the installation. Duchamp insisted on having the notes published in the form of loose paper strips, thereby refraining from any imposition of order or general interpretation onto his work; two boxes of notes were published during his

\footnotetext{
${ }^{73}$ Duchamp worked on the installation from 1915 to 1923, although the studies that led to its creation are dated for 1912 and earlier (Foster 2004: 154, 410). The work was first exhibited in 1926 at the Brooklyn Museum of Art and then accidentally shattered in transit. In 1936, the artist repaired the work by mounting it between two panes and providing an aluminium frame. The Large Glass is now a part of the permanent exhibition at the Philadelphia Museum of Art. A detailed description of the work may be found in Seigel, J. 1997. The Private Worlds of Marcel Duchamp: Desire, Liberation and the Self in Modern Culture. Berkeley and Los Angeles: University of California Press.

${ }^{74}$ For an exhaustive commentary on the readymades refer to de Duve, T. 1991. Pictorial Nominalism: On Marcel Duchamp's Passage from Painting to the Readymade [1984], Minnesapolis: the Minnesota University Press.

${ }^{75}$ Duchamp's notes on The Large Glass were published in Sanouillet M. and E. Peterson (eds). 1989. Salt Seller: The Writings of Marcel Duchamp. Oxford: Oxford University Press.
} 
lifetime and another 100 notes posthumously ${ }^{76}$. The sheer bulk of accumulated material makes The Large Glass one of the most written on works of the past century, consequently providing sufficient grounding for a number of interpretations ${ }^{77}$. The notes, often written in the stream of consciousness technique, are supposed to set the bachelor machine in motion, encouraging the viewer to imagine and actually see the production process on the glass. The viewer is given both visual and verbal stimuli to make sense of the installation, in an avant-garde attempt to break with the retinal aspect of painting in favour of literary multiplicity ${ }^{78}$. The profound impact of Duchamp's work can be explained in terms of relative unfamiliarity of futuristic and avantgarde tendencies in the United States, where he emigrated after the First World War. Although hugely influential, the creator of The Large Glass had never been a leading figure in any of the artistic movements he explored (Joselit 2003: 3). According to David Joselit, the core of Duchamp's art is formed by "strategies of self-multiplication through the invention of discontinuous artistic styles and the adoption of an array of alter egos" (3) - which combined with his "regressive" tendencies to represent "mute materiality or carnality" (5) make his work a perplexing mixture of styles and idioms.

Marcel Duchamp's conceptual idea of The Large Glass could be expounded on in relation to politics and repetition, as explored by Walter Benjamin in his essay on the relation between art and its mechanical reproduction. In Benjamin's view mass appreciation of art destabilised the authenticity of a given work, as technological reproduction shifted its chronological and spatial limitations. Duchamp seems to take the mechanization and reduction of the human body to its critical point in accordance with Benjamin's view that "selfalienation has reached such a degree that it can experience its own destruction as an aesthetic pleasure of the first order" (Benjamin [1936] 1968: 251). Instead of inducing aesthetic appreciation, The Large Glass can be said to represent a rather grotesque form of functionality, being "an eroto-mechanical metaphor, with a logic of function that is as disciplined as it is hilarious" (Ramirez 1998: 77), hence developing and ridiculing themes recurrent in futurist

\footnotetext{
${ }^{76}$ A systematic study of technological and scietific allusions in The Large Glass and in his corpus of notes can be found in Henderson, L. 2005. Duchamp in Context: Science and Technology in The Large Glass and Related Works, Princeton: Princeton University Press. The influence of Rosicrucean and alchemic imagery on Duchamp's art is examined in Moffitt, J. F. 2003. Alchemist of the Avant-Garde: The Case of Marcel Duchamp, New York: State University of New York.

${ }^{77}$ The view is shared by Octavio Paz and other Duchamp scholars; please consult Paz, O. Marcel Duchamp, Appearance Stripped Bare, New York 1978, p.1.

${ }^{78}$ In order to gain a general understanding of the overall working process of Duchamp's machine, refer to a computer animation, created by Andrew Stafford, Making Sense of Marcel Duchamp at http://www.understandingduchamp.com/ DOA 25/10/2010. For additional details on the operation of the machine, see also L. Henderson, Duchamp in Context: Science and Technology in The Large Glass and Related Works, Princeton 2005, plate 82.
} 
and dadaist artistic explorations. In keeping with the specifications of the notes, the mechanism is divided into two domains, namely the bride's and the bachelors'. On the upper glass pane, a fluid and possibly virginal bride blossoms from an engine-like form into a libidinal cloud, whereas, on the lower glass, the bachelor machine is at work with its moulds, uniforms and liveries that represent nine mechanical bachelors ${ }^{79}$. Each of them has a name that corresponds with a particular profession, while their solid vertical shapes contrast with the gaseous, horizontal bride depicted on the other panel.

The Duchampian concept of the bachelor machine follows an imaginative pattern that can be found in the works of such authors like Raymond Roussel or Franz Kafk ${ }^{80}$. Duchamp openly admitted his fascination with the works of Roussel who populated his experimental prose with absurd apparatuses (Seigel 1997: 76, Krauss 1999: 64-65). The bachelor machine, defined by Micheal Carrouges, is understood as "a robotic composition placed outside the closed cycle of birth, life, and death" (Krauss 1999: 180). In this composition the notions of procreation and fecundity are inapplicable, making possible "a dream of infinite celibacy and total autoeroticism" (64). The only product of such mechanical activity is a production of "continual death", or rather absence; in consequence, the nine bachelors seem to produce, consume, and recreate their desire endlessly (64). Therefore, the industrial modus operandi of utility, efficiency and exchange seems to be criticized in The Large Glass by revealing the ties between capitalist values and technology. Furthermore, the bachelor machine is a paradoxical mechanism that operates solely "through breaking down", being in fact "a spectacular (in the sense of extravagant) selfconsumption" (Branden 2003: 238). As a result, the machine produces beyond the rational or the economic rules of a goal-directed activity. According to Braden, Duchamp's machine generates a certain moment of identity opening, a deadly lacuna, which can be considered synonymous with "extravagant waste, destruction, polymorphous sexuality and semiotic excess" (238). The machine itself appears to contradict the notions of progress and forwardness, giving primacy to failure. Through its production, the bachelor machine questions the categories of signification, production, and reproduction.

In The Large Glass, Duchamp pays an ironic homage to the beginnings of modern science in $17^{\text {th }}$ century. The seemingly modern technologies that constitute the bodies of the bride and the bachelors are not technologically advanced; they are reminiscent of windmills, clocks, spring mechanisms and hydraulic automata (Hopkins 1998: 27). The technology that constitutes the inor-

\footnotetext{
${ }^{79}$ For additional details on operation of the machine, see also L. Henderson, Duchamp in Context: Science and Technology in The Large Glass and Related Works, Princeton 2005, plate 82.

${ }^{80}$ Cinema is also described as a form of the bachelor machine, see R. E. Krauss, Bachelors, Cambridge USA and London UK 1999, p. 64.
} 
ganic bodies of the characters in this narrative is helplessly reduced, as if falling behind the evolution in an irreversible image of decadent selfdestruction. The mechanism of desire portrayed by Duchamp is not a purposeful operative composition, rather it is a mechanism for mechanism's sake, where the workers' bodies have been reduced to pure energy flows integrated into the circuit. Their bodies are constrained rather than extended by the technology that envelops them, manifesting a fear of human instrumentalisation in overtly technicised societies. In a way, the bachelor machine is the ultimate body, for

the comparison of body with a machine presupposes that [hu]man is composed of automated mechanical parts reliant on an energy source that produces motor effect over time; and continues to do so well after the original (human or animal) energy has dissipated. (Canguilheim 1992: 48)

It is uncertain whether the bride and bachelors are indeed organically different from the sum of their parts; in other words, without the tell-tale title, it would be impossible to see the bride and the bachelors on the glass. The installation depends on the title for the meaning, resembling a photograph in its use of glass as a medium that connotes "mute verism and resistance to interpretation" (Foster 2004: 154). The bride's halo could equally well be a libidinal cloud, a toxic smoke or a manifestation of a soul. The ontological ambiguity of the objects depicted on the glass panel willfully distorts the Cartesian separation of the mental and the physical, which encouraged viewing the mind as a source of consciousness that was supposed to preside over and govern the body, seen as a machinic object, amenable to treatment and repair, thus having "unconsciously expressed the imperatives of a capitalist economy" (Hopkins 1998: 51). Although unavoidably dualistic, from this perspective, The Large Glass may be said to be a materialist portrayal of a grotesque psyche that fused economic production with reproduction of social relations.

Duchamp's machine should also be situated in the surrealist tradition of death and eroticism, where the constantly frustrated and regenerated desire is created. According to the psychoanalytic dictum, this perfect perpetuum mobile should be interpreted as a phallic symbol of the masculine (Tenhaaf [1992] 2001: 379). To put it differently, the bachelor machine stands for technology that instrumentally stimulates the absent body, placing emphasis on denial, "celibacy, autoeroticism and death" (379). Under these circumstances, The Bride Stripped Bare should also be seen as an attempt at representing a technologically fetishized pornographic male fantasy as well as a mythical frame where the male is designated as the point of origin (380). The concept of the mechanism lies in the will to dismiss the mystery of life and replace it with an endless play of male and female representations. After all, the feminine cloud represented in the upper glass is not entirely necessary for the mechanism to work, because the bachelors' desire is the engine's motor. The feminine mechanism depicted on the painting seems to be "an ironic, self-conscious, even 
whimsical construct" (380); the bride is stripped, therefore also unrealised, her desire is imaginary and escapes the male self-representation, rationalising the autoerotic fantasy of mastery over nature (Hopkins 1998: 26). In the universe of the installation, the bachelor is neither father, nor mother, but an "androgynous anima and celibate priest incarnating god, the archetypal creator himself" (Tenhaaf [1992] 2001: 380). In this work of art, the primacy of male power over nature is ultimate, as nature is depicted as a feminine matrix that sets the bachelor machine in motion but is expendable in every other respect. Moreover, the upper "feminine" glass of the painting is an implicit part of the machine with no position in the symbolic order, in contrast to the lower "masculine" part that is granted the positive symbolic position of a subject. The bride remains a powerfully absent object of optical/visual consumption for the bachelors that peer in through the holes in the vertical line dividing the two spheres. Duchamp's fragmentary and fluid feminine is an example of the mechanical bride as described by Marshall MacLuhan, indicating a "troubling cultural confusion of sex, technology, and death" (MacLuhan [1951] in Caputi 2004: 389). The self-contained circuit of the bachelor machine emphasises the openness and the violability of the bride's domain; even though it reduces the possibility of an intercourse to a chance event, the bride's realm still serves as an unattainable mythical territory to be claimed by the bachelor machine. Despite being a cubist geometrical insecticide form, the feminine body is still rendered as inscribed with love and procreation within the sacred heterosexual union ${ }^{81}$. The modernist painting in an ironic way reproduces the existing relations of power, recapitulating a phallic narrative of eternal life and female death (Krauss 1999: 64). The self-perpetuating libidinal investment depicted by the machine may also be interpreted as a commentary on the artist's way of looking and the position of a female model as an object of contemplation. Duchamp seems to be reinforcing the idea behind Nude Descending a Staircase; the bride, not unlike the nude, is locked in perpetual motion as a shape-shifting object to be looked at by maculinist artists-creators whose viewing position she may never attain.

Caught in between the two glass panels, Duchamp's work is frozen in time and space. Thanks to the use of glass as a medium, The Bride Stripped Bare by her Bachelors, Even gained transparency, multiple perspective and ethereality. Transparency could be regarded as one of the greatest fascinations of the art of the last century, because it embodies the desire to see more and see through, but also to see differently, through the reflections and inferences of images. In this artwork, the quality of being transparent is the effect of a conscious effort by the artist to endow viewers with the feeling of being on the

\footnotetext{
${ }^{81}$ The discussion of gender relations in The Large Glass herein is limited to general assumptions; for a more detailed study of the topic, including an account of Duchamp's Catholic fetishism, refer to D. Hopkins, Marcel Duchamp and Max Ernst: The bride shared, Oxford and New York 1998.
} 
other side of the glass, a feeling of non-representative and dim interior. Octavio Paz recapitulates the conflictual dependency of the viewer on the glass mirror:

it is the glass that separates us from the desired object at the same time as it allows it to be seen. The glass of otherness and identity, we can neither break it nor elude it because the image it reveals to us is that of ourselves in the moment we perceive it through looking. (Paz in Kozlarek 2010: 126)

This mirror, which may as well be a shop window ${ }^{82}$, signifies the process of identifying with the representation of self. In a caricature of erotic contact, the bachelors, and probably the bride too, are immersed in mutual narcissism; their bodies "disappear in the universe of misrecognized masks and eroticism functions as a point of transfer between carnality and the mental aporia" (Joselit 2001: 128). Duchamp's fascination with drag and the fact that the first three letters of Mariée (bride) and Célibataires (bachelors) together form the word Marcel give reason to suppose that The Large Glass is an ironic selfportrait $^{83}$. Above all, the bachelor machine, or rather a mechanised soul in a mechanised body, is a commodity which operates by breaking down, therefore, by definition frustrating desire instead of satisfying it.

At the time of constructing The Large Glass, Marcel Duchamp was interested in mathematics and geometry, particularly in the speculative problem of the fourth dimension (Seigel 1997: 102). The additional dimension could be considered a mathematical utopia, as the world of four dimensions cannot be perceived with senses suited to that of three dimensions. Seigel states that it was an intention of the artist to relegate the bride to the fourth dimension and further explains her lack of solidity and libidinal cloud in terms of "aesthetic existence, where imagination never has to give way to the conditions and limits of life" (105). Duchamp intended to remove The Bride Stripped Bare by her Bachelor, Even from the medium of painting, and for that reason he added another subtitle to the work, naming it Delay in Glass (Perloff 2002: 86). The notion of delay, both abstract and impersonal, was used to convey the poetics of a freeze-framed mechanism at work (86). Further mathematical context for the work is provided by Edwin A. Abott's satire on the Victorian class system in the late $19^{\text {th }}$ century. His Flatland: Romance in Many Dimensions depicts a world populated by two-dimensional figures with clearly defined social roles. Triangles belong to the lower order, above them are squares which, in turn,

\footnotetext{
${ }^{82}$ Duchamp mentions shop windows as an important point of reference for his work, assuming them to be "a proof of outside reality (Duchamp in Seigel [1911] 1997: 29-30, 35).

${ }^{83}$ Around 1920 Duchamp created a feminine persona Rrose Sélavy, famously photographed by Man Ray. The name is supposed to be read as "eros, c'est la vie", thus in an implicit manner "designating sexuality as the source of the energy that undermined fixity" reflected in his work (Seigel 1997: 64). The act of assuming a second identity coincided with a transition in his artistic interests from machines to optical illusions (Foster 2004: 159).
} 
are presided over by pentagons, hexagons and other polygons. The elites of the society are polygonal figures close to attaining the desired ideal of circular shape. Women in this two-dimensional world are lines, and as they have no sides, they belong to the lowliest order of all. For the inhabitants of Flatland, their world is a self-contained system supported by manipulating the aspirations of the lower social classes and disenfranchising lines and nonsymmertical figures. Duchamp's work seems to serve a similar purpose of satirizing the existing social relations with a painting that combines the primitive and the mechanical to depict an apparatus dedicated to heroic production of forever thwarted desire in industralised societies.

The installation marks a turning point in the artist's analysis of commodification and rationalisation of the body as a mechanical analogy and directs his attention towards the mechanics of the mind. The Large Glass is often seen as one of the models for the philosophical concept of a desiring-machine (Joselit 2001: 6). The Duchampian machine is reconfigured as "a switching station ... between the modern rationalisation of the body and newly developing techniques of disciplining the mind" (6). Owing to the earlier discussion of the installation, the work of art can be recognized as an exercise in creative reduction of the commodified body to a mechanical portrayal of the unconscious. Between the glass panes of the painting, there is no escape from the disciplining techniques that keep the working of the unconscious in check and ensure that its production is unrealized and self-contained. Although the machine is a failure in the capitalist world, it seems to fulfil its role of representing a mental phenomenon which is non-manifest in the outside world, once it is embedded in the fourth dimension. However, The Large Glass also appears to demonstrate that the mechanical model of the irrational mind is bound by the matrix of ideas that condition everyday life, by implication projecting the existing relations of inequality into its very core. Duchamp's machine "runs on words" (Suquet in Joselit 2001: 114), the bachelors chant litanies and the bride sends messages to them. Therefore one could assume that language is of utmost importance in the Duchampian constitution of the unconscious, in fact being the only access point to the rational and the irrational workings of the mind. Accordingly, The Large Glass, complemented by the author's prolific notes, can be considered an illustration of the psychoanalytic mechanisation of the human mind, in terms of complexes, drives, hidden desires and automatic reactions.

Metaphorically situated halfway between Sigmund Freud and Henry Ford, The Bride Stripped Bare by her Bachelors, Even represents an amalgam of maniacal production and uncompromising sexualisation. The avowed nihilism of the construction is tempered by its tragically unrealisable potential clogged between the wheels of the machine. This view of mechanical production is later redeveloped by Deleuze and Guattari who, in their concept of the body without organs, propose a fusion of the political and the psychoanalytical 
producing flows of energy and potentialities. In their speculative construction, the social is only accessible through a mechanical production of desire, which is itself a form of production, thus abolishing "the artificial boundary separating the machinations of desire from the realities of history" (Buchanan 2008: 39). Their machinic idea of desire redirects its analysis towards more complicated conceptual fields than need or lack. In support of the above verifications of the Lacanian thought, Deleuze and Guattari give evidence based on schizophrenic delirium and centred on production and reproduction of the subject. They claim that the fulfilment of the actual desire is less important than its reproduction and employ metaphors of mechanical processes in order to illustrate self-actualisation at work. Furthermore, the philosophers "insist on schizophrenia's inherent creativity" (Buchanan 2008: 43) and seek to restore the wholeness of multiple discourses to the body by using eclectic literary and artistic examples of schizophrenic desiring-machines. Their desiringproduction is truly schizophrenic, since it cannot be assimilated by what they term the socius, meaning social production and reproduction (Deleuze and Guattari 1983: 189; Buchanan 2008: 44). In the case of schizophrenia, the illness, being the desiring-machine, eclipses the socius (Deleuze and Guattari 1983: 32), thereby making possible an inquiry into the functioning of the unconscious.

The concept of the Body without Organs (BwO) denotes a "substrate that is also identified as the plane of consistence (as a non-formed, non-organized, non-stratified or destratified body or term)" (Parr 2005: 32); it is both inherent in and independent of the socius, as the subversion process is regarded as ever incomplete. The BwO cannot be seen as "an organ-less body" (33); it still contains the organs, but is opposed to their pyramidal organisation in the form of an organism (Deleuze and Guattari 2005: 179). Deleuze and Guattari call into question "the world of the articulating, self-defining and enclosed subject" and prescribe an "antidote" BwO, which is "precendent, antecedent and even correlate" to the organism; in other words, they substitute the Oedipal lack with "a productive machine that is multiple and in a state of constant flux" (Parr 2005: 32). By the same token, they propose "to remove the poles of organisation but maintain a mode of articulation", and reject language as a means of "arbitrating truth and reality against madness and the presymbolic real" (34). In this equation of maniacal productivity and chaotic negation of order, "the real is the end product, the result of the passive syntheses of desire as the autoproduction of the unconscious" (Deleuze and Guattari 1983: 28). The philosophers redefine desire as multiple, thus proclaiming a revolutionary anti-productivity of the unconscious that averts social exploitation and psychic repression. Unlike psychoanalysis, their schizoanalysis affirms that subjectivity is inherently unstable and operates through proliferation, juxtaposition and disjunction: 
[t]he automata stop dead and set free the unorganized mass they once served to articulate. The full body without organs is the unproductive, the sterile, the unengendered, the unconsumable. Desiring-machines work only when they break down, and continually breaking down. (Deleuze and Guattari 1983: 8)

The failure of the machine is an obligatory condition of infinite production and ensures that the end product is indistinguishable from the process of production. This assertion provides a desirable metaphor for a new mode of prolific production, free of Oedipus, its literary antecedent. In the writings of Deleuze and Guattari, the bodies are multiple; they are human, animal, textual, sociocultural, psychic and physical:

[t]he body without organs is not the proof of an original nothingness, nor is it what remains of a lost totality. Above all, it is not a projection; it has nothing whatsoever to do with the body itself, or with an image of the body (Deleuze and Guattari 1983: 8).

The desiring-machine curbs the body without organs, thus engaging in the process of antiproduction and integrating it into the very process "in the way that interruptions or breakdowns in functioning of the technical machine are integral to its operations" (Tenhaaf [1992] 2001: 387). In a similar manner, schizophrenia interrupts and sustains the functioning of the real (387). Most importantly, Deleuze and Guattari assert that both production and antiproduction are creative and constitute the core of identity, despite the apparent circularity and complexity of the processes at work.

Duchamp as well as Deleuze and Guattari work within the premise of a psychoanalytic mechanical mind, in essence regular and controllable. Even though their definitions of a machine are radically different, they give precedence to malfunctioning mechanisms, governed by the productive and reproductive tyranny of desire. They differ in viewing desire as a productive form; Duchamp's The Large Glass represents erotic desire in a radically reduced mechanical form as endless, meaningless and senseless, whereas Deleuze and Guattari seem to accept and even embrace the counter-productivity of such a desire. Significantly enough, they seek to celebrate the multiplicity of mechanical production by incorporating repressive and oppressive impulses within the desiring-machine. It appears that the bachelor machine falls victim to the capitalist rule of minimizing effort and maximizing gain by taking this rule to a critical point of self-destruction. In terms of schizoanalysis, the Duchampian mechanism is solely preoccupied with the production of its own repression, and, in consequence, loses the liberatory and revolutionary potential of an unbound production, typical for the desiring-machines. The bachelor machine with its fantasies, organic insufficiency, and mediatisation of desire through the other, could be perceived as a mechanical model for the psychoanalytic conception of consciousness, wherein the automated drives and complexes assure a regulated production of subjectivity by faithfully reproducing the 
existing power relations. Such an interpretation is further reinforced by the use of glass as a material that gives a perspectival impression of suprapersonal rationality.

Dissatisfied with this understanding of desire, Deleuze and Guattari advocated anti-production that escapes the dichotomous and hierarchical linguistic categorisation. According to their discourse of productivity, the internalization of the scientific discourse on the unconscious is never complete and requires unceasing reproduction and production, wherein the body without organs repeatedly rebels against its own repression, rendering the whole process polyvalent and multiple. The whole process of such production is possible, because "[t]he schizophrenic is the universal producer. There is no need to distinguish here between producing and its product" (Deleuze and Guattari 1983: 8). The body without organs is integrated into the process of production in which the Oedipal complex is merely one consequence of social production. Deleuze and Guattari rely on the conception of the body as a site of biomedically stipulated physicality (as in the body with organs) and propose that bodies are interlocked conglomerates dependable on many variables. This openended conception challenges the deterministic assumptions of self-enclosed subjectivity and celebrates active agency that takes on the form of various, temporal or permanent, connections and assemblages. Ian Buchanan, in his essay on the question of the body in the work of Deleuze and Guattari, traces this idea back to Deleuze's interest in the Spinozist view of reality as simultaneously mental and physical, stating that the BwO is not the starting point but the postulated outcome of "an attempt to replace aetiology (cause and effect) with ethology (action and affect)" made in Anti-Oedipus (1997:74). The continually reconfigured disequilibrium of the body without organs produces affects that render bodily experiences accessible and context-specific.

Undoubtedly, there are some correspondences between The Large Glass and Anti-Oedipus; both works are scandalous and eloquent, providing the reader with a confusing mixture of scientific speculation and literary effusion. The mechanical production of desire depicted by Duchamp operates on a single plane of affection and limits the body's capacity for interaction outside the obsessive circle of voyeristic desire. In this respect the Duchampian machine could be defined as "an analysis of repressive forces [that] homogenized affect by standardizing its expression" (Zepke 2008: 42). It seems that Duchamp concentrates on the disciplining function of the technological metaphor, while Deleuze and Guattari strive to reposition desire as plural and incoherent, by introducing the economy of desire into the productive work of the desiringmachine. Deleuze and Guattari's desiring-machines perform the role of an intermediary between the body and the body without organs that stands for desire itself. Through using the matrix of a machine, their schizoanalysis seeks to restore the discontinuous flow of desire and to disrupt the economy of a repressed self. In contrast to Duchamp, the French philosophers did not 
intend to emphasise mindless automation, but favoured the mechanism's seemingly endless ability to make connections, to produce relationships between disparate elements, such as bodies, the environment, regimes of power and technologies available. Still, The Large Glass made by Duchamp in the period characterised by the rise of military industralism and mass production represents a complex social interaction in the form of a primitive mechanism that humourously caricatures the teleogical assumptions of modernists. Although his installation, guided by the principle of separation with two domains containing two disconnected mechanisms, was made almost half a century before Deleuze and Guattari's cooperation, it provides a crucial context for their integrative approach that suggested intertwined planes of coexistence between the biological and the technological. From this analeptic perspective, the bachelor machine and its convoluted narrative of complicated operations may be seen as a failed attempt at reterritorialising a unified identity that is forever enfolded between the double helix of the bride and the bachelors.

\section{References}

Abbott, E. A. 2006. Flatland: A Romance of Many Dimensions (1884). ed. Rosemary Jann. New York: Oxford University Press.

Branden, W. J. 2003. Random Order: Robert Rauschenberg and the Neo-avant-garde. Cambridge: The MIT Press.

Benjamin, W. 1968. The Work of Art in the Age of Mechanical Reproduction (1936). H. Arendt, ed. Benjamin, Illuminations.trans. by H. Zohn. New York: Schocken Books.

Buchanan, I. 2008. Deleuze and Guattari's Anti-Oedipus: A Reader's Guide. London: Bloomsbury Academic.

Buchanan, I. 1997. The Problem of the Body in Deleuze and Guattari, Or, What Can a Body Do? Body Society 3: 73-91.

Caputi, J. 2004. Goddesses and Monsters: Women, Myth, Power, and Popular Culture. Wisconsin: The University of Wisconsin Press.

Canguilheim, G. 1992. Machine and Organism. J. Crary and S. Kwinter, eds. Incorporations. New York: Zone Books.

Deleuze, G. and F. Guattari. 1983. The Anti-Oedipus: Capitalism and Schizofrenia (1972). trans. by R. Hutley, M. Seem and H.R. Lane. Minneapolis: University of Minnesota Press.

Deleuze, G. and F. Guattari. 2005. A Thousand Plateaus: Capitalisma and Schizofrenia (1980). trans. by B. Massumi. Minneapolis: University of Minnesota Press.

Duchamp, M. 1989. Salt Seller: The Writings of Marcel Duchamp. M. Sanouillet and E. Peterson, eds. Oxford: Oxford University Press. 
de Duve, T. 1991. Pictorial Nominalism: On Marcel Duchamp's Passage from Painting to the Readymade (1984). trans. by Dana Polan with the Author. Minnesapolis: the University of Minnesota Press.

Foster, H. and R. Krauss, Y.-A. Bois, B. Buchloh, D. Joselit. 2004. Art Since 1900. Modernims, Antimodernism, Postmodernism. London: Thames and Hudson.

Henderson, L. 2005. Duchamp in Context: Science and Technology in The Large Glass and Related Works. Princeton: Princenton University Press.

Hopkins, D. 1998. Marcel Duchamp and Max Ernst: The Bride Shared. Oxford: Oxford University Press.

Joselit, D. 2001. Infinite Regress: Marcel Duchamp 1910-1941. Cambridge: The MIT Press.

Kozlarek, O. (ed) 2010. Octavio Paz: Humanism and Critique. Bielefeld: Transcript.

Krauss, R. E. 1999. Bachelors. Cambridge: The MIT Press.

Moffitt, J. F. 2003. Alchemist of the Avant-Garde: The Case of Marcel Duchamp. New York: State University of New York.

Parr A. (ed.) 2005. The Deleuze Dictionary. Edinburgh: Edinburgh University Press.

Paz, O. 1978. Marcel Ducham, Appearance Stripped Bare. New York: Viking Press.

Perloff, M. 2002. 21st-century Modernism: The 'New' Poetics. Blackwell Manifestos. Oxford: Wiley.

Ramirez, J. A. 1998. Duchamp: Love and Death, Even. London: Reaktion Books.

Seigel, J. 1997. The Private Worlds of Marcel Duchamp: Desire, Liberation and the Self in Modern Culture. Berkeley and Los Angeles: University of California Press.

Tenhaaf, N. 2001. "Of Monitors and Men and Other Unsolved Feminist Mysteries: Video Technology and the Feminine” (1992). H. Robinson, Feminism-Art-Theory: An Anthology, 1968-2000. Oxford and Mladen: Wiley Publishing.

Zepke, S. 2008. The Readymade: Art as the Refrain of Life. S. O'Sullivan and S. Zepke. Deleuze, Guattari and the Production of the New. London and New York: Continuum Publishing.

\section{Internet sources}

A. Stafford, Making Sense of Marcel Duchamp DOA 25/10/2010. http://www.understandingduchamp.com

Philadelphia Museum of Art, permanent collections, The Large Glass http://www.philamuseum.org/collections/permanent/54149.html 


\begin{abstract}
Abstrakt
Celem niniejszego eseju jest refleksja nad mechanizacją pragnienia w Wielkiej szybie autorstwa Marcela Duchampa. Instalacja w formie oprawionej szklanej tafli przedstawia skomplikowany mechanizm, który, jak sugeruje pełny tytuł dzieła, przedstawia Pannę młoda rozebraną przez swoich zalotników, równo. Duchamp, posługując się tropami i figurami z poprzednich prac, zaprojektował maszynę do produkcji pragnienia, tworząc tym samym mechaniczną i dynamiczną wizję nieświadomości. Niniejszy artykuł analizuje wybrane aspekty instalacji, począwszy od mechanicznej reprodukcji (1), fetyszyzmu technologicznego (2), przejrzystości (3), na zakończenie odnosząc się do koncepcji Ciała bez organów zaproponowanej przez Deleuze’a i Guattariego (4). Interpretatywne kwestie dotyczące metaforyki maszyny w instalacji Duchampa zostaną zaprezentowane w kontekście integrującego i nie-integrującego podejścia do technologii.
\end{abstract}

Słowa kluczowe: Duchamp; fetyszyzm technologiczny; mechaniczna reprodukcja; Deleuze i Guattari; Ciało bez organów. 